\title{
Efektivitas Ekstrak Artemisia vulgaris sebagai Suplementasi terhadap Kemoterapi Adenokarsinoma Mammae dalam Meningkatkan IL-12 dan Indeks Apoptosis Sel Kanker
} (Studi pada Mencit C3H yang Diberi Regimen Kemoterapi Adriamycin-Cyclophosphamide)

\section{The Effectivity of Artemisia vulgaris Extract as Supplementation to Adenocarcinoma Mammae Chemotherapy for Increasing IL-12 and Apoptotic Index}

(Study on C3H Mice Given Adriamycin-Cyclophosphamide Chemotherapy Regimen)

\author{
Antonio Paulus', Selamat Budijitno ${ }^{2}$, Benny Issakh ${ }^{2}$ \\ ${ }^{1}$ Residen Bedah Umum Fakultas Kedokteran Universitas Diponegoro Semarang \\ ${ }^{2}$ Sub Bagian Onkologi Bedah Tumor dan Kepala Leher Fakultas Kedokteran Universitas Diponegoro Semarang
}

\begin{abstract}
ABSTRAK
Insiden kanker payudara di seluruh dunia masih tinggi. Pembedahan tetap merupakan pilihan utama dengan modalitas lain berupa kemoterapi, radiasi, dan imunoterapi antara lain Artemisia vulgaris (AV). Penelitian dilakukan untuk membuktikan efek pemberian ekstrak AV terhadap kadar IL-12 dan indeks apoptosis sel kanker pada adenokarsinoma mammae. Penelitian ini menggunakan desain post test only control group design menggunakan 24 ekor mencit $\mathrm{C} 3 \mathrm{H}$ betina yang dibagi secara acak menjadi empat kelompok, yaitu: K (kontrol), P1 (kemoterapi), P2 (ekstrak AV), dan P3 (kombinasi kemoterapi dan ekstrak AV). Adriamycin 0,18mg dan Cyclophosphamide 1,8mg diberikan sebanyak 2 siklus. Ekstrak AV diberikan $13 \mathrm{mg}(0,2 \mathrm{ml})$ perhari. Kadar IL-12 dinilai dengan pengecatan imunohistokimia sedangkan indeks apoptosis dengan hematoxilin eosin. Rerata kadar IL-12 dan indeks apoptosis didapatkan K, P1, P2, P3 berturut-turut

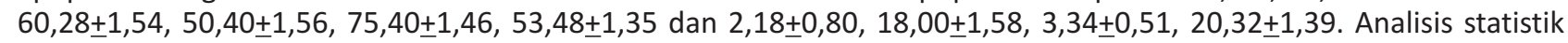
menunjukkan terdapat perbedaan bermakna pada kadar IL-12 antara kelompok K vs P1, P2, P3 ( $p=0,001), P 1$ vs P2 $(p=0,001), P 1$ vs $P 3(p=0,028), P 2$ vs $P 3(p=0,001)$ dan indeks apoptosis antara kelompok K vs $P 1, P 3(p=0,001), P 1$ vs P2 $(p=0,001), P 1$ vs P3 $(p=0,035), P 2$ vs P3 $(p=0,001)$. Terdapat hubungan positif kuat yang signifikan antara kadar IL-12 dengan indeks apoptosis ( $p=0,041$ dan $r=0,893)$. Pemberian ekstrak Artemisia vulgaris dapat meningkatkan kadar IL-12 dan indeks apoptosis sel kanker pada mencit $\mathrm{C} 3 \mathrm{H}$ dengan adenokarsinoma mammae yang diberi regimen kemoterapi Adriamycin-Cyclophosphamide.
\end{abstract}

Kata Kunci: Adenokarsinoma mammae, Artemisia vulgaris, imunoterapi, indeks apoptosis, kadar IL-12

\begin{abstract}
The incidence of breast cancer worldwide is still high. Surgery remains the top choice with other modalities of chemotherapy, radiation, and immunotherapy such as Artemisia vulgaris (AV). The study was aimed to demonstrate the effect of AV extract administration on IL-12 level and apoptosis index of cancer cells in adenocarcinoma mammary. This study used a posttest only control group design using 24 female $\mathrm{C} 3 \mathrm{H}$ mice which were divided randomly into four groups, namely C (control), P1 (chemotherapy), P2 (AV extract), and P3 (combination chemotherapy and AV extract). Adriamycin $0,18 \mathrm{mg}$ and Cyclophosphamide $1,8 \mathrm{mg}$ were given in 2 cycles. AV $13 \mathrm{mg}(0.2 \mathrm{ml})$ was given daily. IL-12 levels were evaluated using immunohistochemical staining while the apoptotic index was by Hematoxilin Eosin. Mean of IL-12 levels and apoptotic index in groups $K, P 1, P 2, P 3$ were $60.8 \pm 1.54,50.40 \pm 1.56,75.40 \pm 1.46,53.48 \pm 1.35$, and 2.18 $\pm 0.80,18.00 \pm 1.58$, $3.34 \pm 0.51,20.32 \pm 1.39$ respectively. The statistical analysis showed that there were significant differences in the levels of $I L-12$ between groups of $K$ vs $P 1, P 2, P 3(p=0.001), P 1$ vs $P 2(p=0.001), P 1$ vs $P 3(p=0.028), P 2$ vs $P 3(p=0.001)$, and in apoptotic index between groups of K vs $P 1, P 3(p=0.001), P 1$ vs $P 2(p=0.001), P 1$ vs $P 3(p=0.035), P 2$ vs $P 3(p=0.001)$. There was a significant positive correlation between IL-12 levels and apoptosis index ( $p=0.041$ and $r=0.893)$. The administration of Artemisia vulgaris extract can increase IL-12 levels and apoptosis index of cancer cells in C3H mice with mammary adenocarcinoma given Adriamycin-Cyclophosphamide chemotherapy regimen.
\end{abstract}

Keywords: Artemisia vulgaris, adenocarcinoma mammae, IL-12 levels, apoptosis index.

Korespondensi: Antonio Paulus. Residen Bedah Umum Fakultas Kedokteran Universitas Diponegoro Semarang, Jl. Prof. H. Soedarto SH, Tembalang, Jawa Tengah Tel.(024)76928010Email: paupau120685@gmail.com 


\section{PENDAHULUAN}

Kanker masih menempati urutan kedua penyebab kematian di dunia setelah penyakit kardiovaskular. Data GLOBOCAN, International Agency for Research on Cancer (IARC), menyebutkan pada tahun 2012 ditemukan 14 juta kasus baru kanker. Sebanyak 7,5 juta orang meninggal akibat kanker, serta 70\% kematian akibat kanker terjadi di negara miskin dan berkembang. Jenis kanker terbanyak pada perempuan adalah kanker payudara (38 per 100.000 perempuan) (1). Data Riskesdas 2013 menunjukkan prevalensi kanker di Indonesia adalah 1,4 per 1.000 penduduk, serta merupakan penyebab kematian nomor 7 (5,7\%). Globocan/IARC 2012 melaporkan estimasi insiden kanker payudara di Indonesia adalah 40 per 100.000 perempuan. Prevalensi kanker payudara ini lebih tinggi bila dibandingkan dengan tahun 2002 yaitu 26 per 100.000 perempuan. Pasien kanker terbanyak yang dirawat inap di rumah sakit seluruh Indonesia pada tahun 2010 adalah pasien kanker payudara $(28,7 \%)(1)$. Selain pada wanita, penyakit ini dapat diderita kaum laki-laki dengan frekuensi sekitar 1\%. Lebih dari 80\% kasus kanker payudara ditemukan pada stadium lanjut, dimana angka keberhasilan terapi rendah (2).

Modalitas terapi kanker payudara meliputi pembedahan, kemoterapi, radioterapi, terapi imun, dan terapi hormonal. Pembedahan dan radioterapi bersifat lokal, sedangkan kemoterapi, terapi imun, dan terapi hormonal bersifat sistemik. Kemoterapi pada kanker payudara dilakukan dalam bentuk regimen (2). Kombinasi kemoterapi kanker payudara yang digunakan antara lain: Fluorouracil, Adriamycin dan Cyclophosphamide (FAC); Fluorouracil, Epirubicin dan Cyclophosphamide (FEC); Adriamycin dan Cyclophosphamide (AC) dan Cyclophosphamide, Methotrexate dan Fluorouracil (CMF). Kemoterapi ini diberikan dalam interval 3-4 minggu. Regimen FAC, FEC dan CMF diberikan dalam 6 siklus (dalam jangka waktu 18-24 minggu) sedangkan $A C$ diberikan dalam 4 siklus (dalam jangka waktu 12-16 minggu) (3). Angka keberhasilan kemoterapi berdasarkan RECIST 1.1 (Response Evaluation Criteria In Solid Tumors) dilihat dari Complete Response dan Partial Response$C R / P R$. Kemoterapi untuk kanker payudara ini memiliki $C R / P R$ hanya berkisar antara $20 \%-40 \%$, sedangkan obat ini mempunyai efek toksis terhadap organ-organ dalam tubuh dan immunosupresi (4).

Penelitian telah difokuskan pada pengembangan kemoterapi lebih aman dengan mengeksplorasi sifat antikanker senyawa baru, salah satunya yang berasal dari tanaman obat. Banyak turunan tanaman obat yang dikenal efektif melawan berbagai penyakit dengan aktivitas antibiotik dan antimalignant luas (5). Sudah banyak penelitian yang dilakukan mengenai tanaman obat yang digunakan sebagai suplementasi terhadap kemoterapi, antara lain: Mahkota Dewa (Phaleria macrocarpa) (6), Jinten Hitam (Nigella sativa) (7), Teh hijau (Camellia sinensis) (8), Sirsak (Annona muricata) (9), dan Baru Cina (Artemisia vulgaris). Artemisia vulgaris memiliki efek sitotoksik yang selektif terhadap sel tumor dan sudah digunakan sebagai suplementasi pada terapi kanker lambung, kolorektal, hepar, kantung empedu, pankreas, ginjal, prostat, dan kanker kulit (10-13). Pemanfaatan Artemisia vulgaris sebagai tanaman obat untuk suplementasi terhadap kemoterapi untuk kanker payudara masih memerlukan suatu pembuktian.

Penelitian sebelumnya pada Artemisia vulgaris menunjukkan adanya kandungan golongan phenols, flavonoid, sesquiterpenoid (artemisinin dan derivatnya), dan coumarin (scopoletin) (14). Artemisinin dan derivatnya sudah digunakan sebagai obat antimalaria, namun juga menunjukkan aktivitas sitotoksik terhadap sel kanker melalui induksi apoptosis, menghambat aktivitas angiogenesis, disrupsi siklus sel kanker, dan toksisitas radikal bebas. Artemisinin diketahui mempunyai struktur molekul yang mengandung jembatan peroksida (15). Meskipun bersifat sitotoksik, artemisinin memiliki keuntungan dapat digunakan sebagai antikanker karena memiliki sifat toksik yang selektif. Hal ini menjadi pertimbangan penting dalam hal keamanan bagi para penggunanya. Sifat sitotoksik yang selektif pada Artemisia vulgaris menjadi faktor pendukung dilakukan penelitian pendahuluan pada tahap pre-klinik (16). Penelitian sebelumnya yang dilakukan pada mencit yang menderita karsinoma kantung empedu dengan dosis $100 \mathrm{mg} / \mathrm{kg}$ per hari artemisinin menunjukan aktivitas antikanker (17).

Interleukin-12 (IL-12) adalah sitokin pleiotropik yang menciptakan interkoneksi antara kekebalan bawaan dan adaptif. Berdasarkan fungsinya, IL-12 pada awalnya ditetapkan sebagai faktor pematangan limfosit sitotoksik dan stimulasi sel pembunuh alami. Interleukin-12 tampak sebagai calon ideal untuk imunoterapi tumor pada manusia karena menjembatani kekebalan bawaan dan adaptif dan dengan potensi merangsang produksi IFN- $\gamma$ sitokin yang mengoordinasikan mekanisme alami pertahanan antikanker. Sumber utama IL-12 pada manusia adalah antigen-presenting cell (APC) yang diaktifkan, seperti sel dendritik, serta fagosit hematopoietik (monosit, makrofag, dan juga neutrofil). Interleukin-12 bekerja pada berbagai sel kekebalan tubuh, keseluruhan peran fisiologis IL-12 tampaknya mengatur respons imun tipe-Th1 terhadap patogen tertentu. Disamping itu, ditemukannya berbagai aktivitas imunoregulasi IL-12 meningkatkan minat besar pada sitokin ini sebagai agen antikanker potensial (18-20).

Peran apoptosis dalam fisiologi normal sama pentingnya dengan mitosis. Apoptosis menunjukkan peran komplementer namun berlawanan terhadap mitosis dan proliferasi sel dalam regulasi berbagai populasi sel yang berfungsi menjaga homeostasis pada tubuh manusia dewasa. Kanker adalah contoh kondisi ketika mekanisme normal regulasi siklus sel mengalami disfungsional, dengan over proliferasi sel dan/atau penurunan pemusnahan sel. Penekanan apoptosis selama karsinogenesis dianggap memainkan peran sentral dalam perkembangan dan perkembangan beberapa jenis kanker $(21,22)$.

Penelitian ini dilakukan untuk menguji efektifitas ekstrak Artemisia vulgaris dalam meningkatkan kadar IL-12 dan indeks apoptosis sel kanker pada mencit $\mathrm{C} 3 \mathrm{H}$ dengan adenokarsinoma mammae yang diberi regimen kemoterapi Adriamycin-Cyclophosphamide. Hasil dari penelitian ini diharapkan dapat mendukung penggunaan Artemisia vulgaris sebagai suplementasi terhadap kemoterapi kanker payudara.

\section{METODE}

\section{Rancangan Penelitian}

Penelitian eksperimental ini menggunakan desain "Post test only control group design". Terdapat empat kelompok penelitian yaitu: (1) kontrol, kelompok mencit $\mathrm{C} 3 \mathrm{H}$ yang 
hanya diinokulasi sel kanker, (2) P1, kelompok mencit C3H yang diinokulasi sel kanker, mendapat kemoterapi Adriamycin 0,18 mg dan Cyclophosphamide 1,8 mg secara intravena, (3) P2, kelompok mencit $\mathrm{C} 3 \mathrm{H}$ yang diinokulasi sel kanker, mendapat ekstrak Artemisia vulgaris $13 \mathrm{mg}$ sekali sehari peroral, dan (4) P3, kelompok mencit C3H yang diinokulasi sel kanker, mendapat kemoterapi Adriamycin 0,18mg dan Cyclophosphamide 1,8mg secara intravena dan ekstrak Artemisia vulgaris $13 \mathrm{mg}$ sekali sehari peroral. Inokulasi sel kanker diberikan 1 kali secara subkutan di daerah ketiak menuju ke arah mammae. Dosis pertama kemoterapi diberikan $1 \mathrm{x} /$ hari selama 21 hari dan dosis kedua diberikan pada hari ke 22.

\section{Sampel Penelitian}

Sampel penelitian diperoleh dari PT. IndoAniLab Bogor dengan kriteria inklusi: mencit betina umur 8 minggu, strain $\mathrm{C} 3 \mathrm{H}$ yang berhasil diinokulasi adenokarsinoma mammae, berat badan 20-30 gram setelah masa adaptasi, dan tidak ada abnormalitas anatomis yang tampak. Sampel tidak disertakan dalam perlakuan apabila terjadi regresi tumor setelah dilakukan inokulasi dan selama inokulasi, serta jika selama perlakuan mencit tampak sakit (gerakan tidak aktif). Menurut WHO jumlah pengulangan tiap kelompok minimal 5 ekor dengan cadangan $10 \%$ (23). Pada penelitian ini tiap kelompok digunakan 6 ekor mencit. Selama penelitian, mencit ditempatkan pada kandang terpisah dan diberi pakan sesuai standar. Sebelum perlakuan, mencit menjalani masa adaptasi selama 1 minggu.

\section{Waktu dan Lokasi Penelitian}

Penelitian dilakukan selama 5 bulan. Proses ekstrak Artemisia vulgaris dilakukan di LPPTI Fakultas Kedokteran Universitas Gajah Mada. Perlakuan dan pengambilan jaringan dilakukan di LPPT IV Fakultas Kedokteran Universitas Gajah Mada. Pembuatan blok parafin, pewarnaan $\mathrm{HE}$ dan pewarnaan immunohistokimia dilakukan di Laboratorium Patologi Anatomi Fakultas Kedokteran Universitas Sebelas Maret Surakarta.

\section{Variabel Penelitian}

Perlakuan dalam penelitian ini meliputi pemberian: (1) ekstrak Artemisia vulgaris, (2) AdriamycinCyclophosphamide, dan (3) kombinasi AdriamycinCyclophosphamide dan ekstrak Artemisia vulgaris. Luaran yang diukur adalah kadar interleukin-12 (IL-12) dan indeks apoptosis. Kadar IL-12 dinilai dengan pemeriksaan imunohistokimia, masing-masing sediaan diteliti sebanyak lima lapang pandang. Nilai dari setiap lapang pandang yang dihitung adalah jumlah sel tumor dengan inti berwarna coklat dan dihitung dari 100 sel tumor sebagai nilai untuk memperoleh kadar IL-12 dengan skala ukur rasion. Indeks apoptosis, dihitung sesuai dengan metoda yang digunakan oleh Aihara $M$ et al, yaitu badan apoptotik dihitung per 100 sel tumor pada 5 lapangan pandang kemudian diambil rata-rata hasilnya dengan skala ukur rasio.

\section{Bahan dan Alat Penelitian}

Simplisa Artemisia vulgaris diperoleh dari Unit Konservasi Budidaya Biofarmaka Institut Pertanian Bogor. Ekstrak Artemisia vulgaris diperoleh melalui proses berikut. Tahap pertama satu kilogram daun kering Artemisia vulgaris ditumbuk halus, kemudian dilakukan ekstraksi dengan cara sokletasi menggunakan pelarut etanol dengan siklus 8-10 kali. Hasil ekstrak dimasukkan ke dalam evaporator dan dilakukan destilasi vakum. Ekstrak dikeringkan dengan suhu $40^{\circ} \mathrm{C}$ selama 1 jam untuk menguapkan etanol. Dari proses tersebut dihasilkan $5,5 \mathrm{mg}$ ekstrak pada setiap $1 \mathrm{~kg}$ bahan $(0,55 \%)$ yang kemudian diencerkan dengan aquabidest sampai tercapai konsentrasi $0,2 \mathrm{mg} / \mathrm{ml}$. Adenokarsinoma mammae diperoleh dari mencit donor. Selain ditransplantasikan, tumor dari mencit donor dilakukan insisi biopsi untuk konfirmasi jenis tumor.

\section{Analisis Dato}

Sebelum analisis dilakukan cleaning, coding dan tabulasi. Analisa data yang dilakukan adalah analisis deskriptif dan uji hipotesis. Analisa deskriptif kadar IL-12 dan indeks apoptosis adenokarsinoma mamma disajikan dalam bentuk tabel dan grafik box plot. Dilakukan uji normalitas data dengan uji Saphiro-Wilk. Uji hipotesis yang digunakan adalah uji One Way ANOVA, dilanjutkan dengan Post-Hoc test untuk mengetahui perbedaan antar kelompok. Uji korelasi antara kadar IL-12 dan indeks apoptosis dilakukan dengan uji korelasi Pearson. Batas derajat kemaknaan adalah $p<0,05$ dengan $95 \%$ interval kepercayaan. Analisa data dilakukan dengan SPSS Ver. 21.0 for Windows.

\section{Persyaratan Etik Penelitian}

Penelitian ini menerapkan animal ethics dalam proses pengelolaan hewan coba dan sudah memperoleh persetujuan Komisi Etik Penelitian Kesehatan Fakultas Kedokteran Universitas Diponegoro. Seluruh hewan coba dirawat dan dikelola sesuai standar pemeliharaan binatang.

\section{HASIL}

Efek Artemisin pada Kadar Interleukin-12

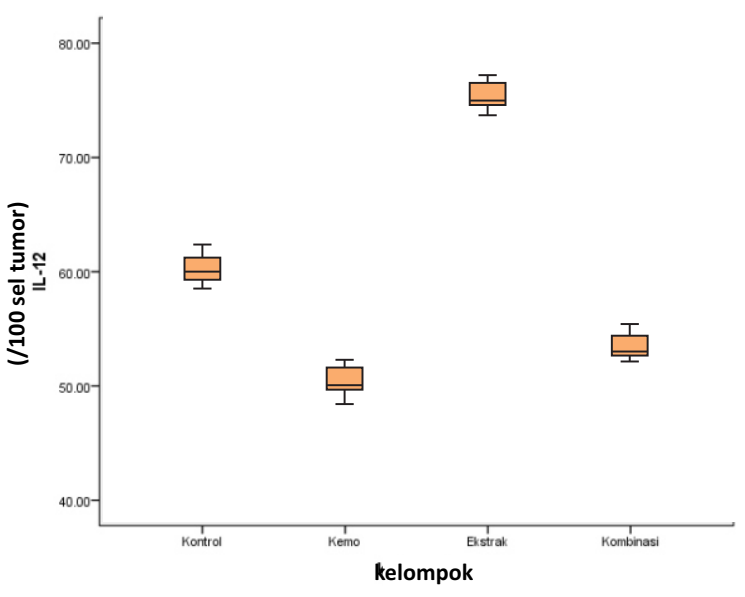

Gambar 1. Grafik box plot data IL-12

Keterangan: Box plot menunjukkan median kadar IL-12 kelompok K (kontrol) lebih rendah dibanding kelompok P2 (ekstrak saja) dan kelompok P1 (kemoterapi saja) lebih rendah dibandingkan kelompok P3 (kombinasi)

Hasil (Gambar 1) menunjukkan rerata kadar IL-12 sel adenokarsinoma mammae yang lebih rendah dari kelompok kontrol adalah perlakuan 1 yang diberikan kemoterapi dan perlakuan tiga yang mendapatkan tambahan ekstrak Artemisia vulgaris $13 \mathrm{mg}$ satu kali perhari, diberikan peroral. Sebaliknya pada kelompok yang hanya mendapatkan Artemisia vulgaris $13 \mathrm{mg} /$ hari, per- 
oral justru menunjukkan rerata rerata kadar IL-12 sel adenokarsinoma mammae yang lebih tinggi.

Uji One Way ANOVA (Tabel 1) menunjukkan perbedaan bermakna kadar IL-12 pada keempat kelompok. Dari hasil uji Bonferroni didapatkan perbedaan yang bermakna antara kelompok kontrol dengan semua kelompok perlakuan P1, P2, dan P3 $(p=0,001)$. Kadar IL-12 pada kelompok dengan pemberian kemoterapi lebih rendah dari pemberian ekstrak artemisin saja $(p=0,001)$ maupun terapi kombinasi $(p=0,028)$. Penambahan artemisin pada kemoterapi memberikan kadar IL-12 yang lebih tinggi bila dibandingkan kemoterapi saja $(p=0,001)$. Nilai tertinggi kadar IL-12 didapatkan pada terapi artemisin.

Tabel 1. Analisis Post Hoc kadar IL-12 antar kelompok

\begin{tabular}{lrrr}
\hline Kelompok & P1 & P2 & P3 \\
\hline K & $0,001^{*}$ & $0,001^{*}$ & $0,001^{*}$ \\
P1 & - & $0,001^{*}$ & $0,028^{*}$ \\
P2 & & - & $0,001^{*}$ \\
\hline
\end{tabular}

Keterangan: *Diuji dengan Bonferroni (signifikan $p<0,05$ )

\section{Efek Artemisin pada Indeks Apoptosis}

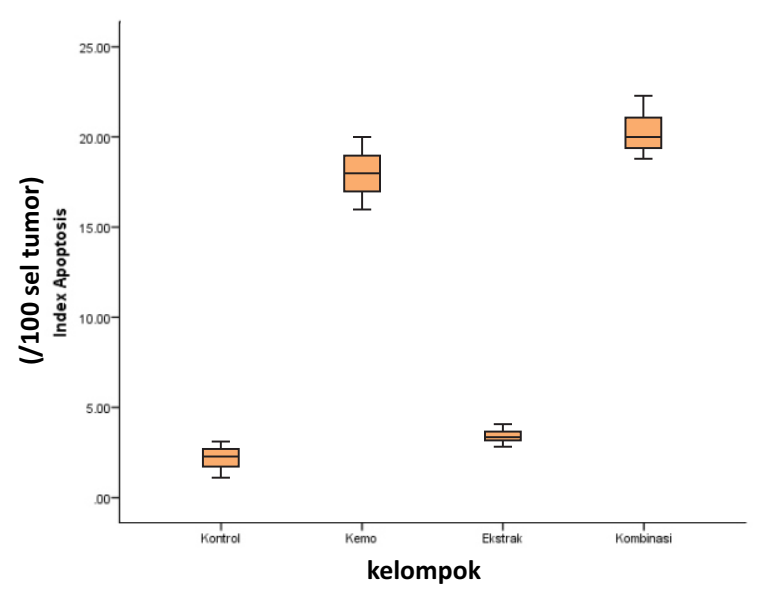

Gambar 2. Grafik box plot data indeks apoptosis

Keterangan: Box plot menunjukkan median indeks apoptosis kelompok $\mathrm{K}$ (kontrol) lebih rendah dibanding kelompok P2 (pemberian ekstrak artemisin), dan kelompok P1 (pemberian kemoterapi) lebih rendah dibandingkan kelompok P3 (kombinasi).

Hasil menunjukkan rerata indeks apoptosis sel adenokarsinoma mammae paling tinggi pada kelompok dengan terapi kombinasi (P3) dan paling rendah pada kelompok kontrol (K). Pemberian artemisin saja memberikan rerata indeks apoptosis yang lebih rendah dibandingkan kemoterapi (Gambar 2).

Hasil uji ANOVA menunjukkan perbedaan bermakna nilai indeks apoptosis pada keempat kelompok. Dari hasil uji Bonferroni didapatkan perbedaan yang bermakna antara kelompok kontrol dengan terapi kemoterapi atau kombinasi namun tidak berbeda dengan kelompok terapi artemisin saja. Kombinasi kemoterapi dan artemisin terbukti memberikan perbedaan indeks apoptosis yang signifikan secara statistik bila dibandingkan hanya kemoterapi atau artemisin. Terapi dengan artemisin saja mempunyai indeks apoptosis yang lebih rendah dari kemoterapi bahkan sama dengan kontrol.

Tabel 2. Analisis Post Hoc indeks apoptosis antar

\begin{tabular}{lccc}
\hline Kelompok & P1 $^{\text {kelompok }}$ & P2 & P3 \\
\hline K & $0,001^{*}$ & 0,792 & $0,001^{*}$ \\
P1 & - & $0,001^{*}$ & $0,035^{*}$ \\
P2 & & - & $0,001^{*}$ \\
\hline
\end{tabular}

Keterangan: * Diuji dengan Bonferroni (signifikan $p<0,05$ )

\section{Korelasi IL-12 dan Indeks Apoptosis}

Uji korelasi antara kadar IL-12 dan indeks apoptosis dilakukan pada kelompok P3 (kombinasi). Analis korelasi Pearsons dipilih oleh karena distribusi data kedua variabel normal dan homogen. Uji menunjukkan terdapat hubungan positif kuat $(R=0,893, p=0,041)$ yang signifikan antara kadar IL-12 dengan indeks apoptosis.

\section{DISKUSI}

Penelitian ini dilakukan untuk melihat efektifitas ekstrak Artemisia vulgaris dalam meningkatkan kadar IL-12 dan indeks apoptosis sel kanker pada mencit $\mathrm{C} 3 \mathrm{H}$ dengan adenokarsinoma mammae yang diberi regimen kemoterapi Adriamycin-Cyclophosphamide. Pemberian kemoterapi hanya diberikan 2 siklus saja dari 4 siklus yang direkomendasikan sesuai pemberian pada manusia (26). Hasil menunjukkan bahwa rerata kadar IL-12 ditemukan lebih tinggi pada kelompok kombinasi kemoterapi dan ekstrak Artemisia vulgaris dibandingkan kemoterapi saja. Kadar IL-12 pada kelompok dengan terapi kombinasi yang lebih tinggi dibandingkan dengan kelompok kemoterapi saja mengindikasikan ekstrak Artemisia vulgaris memperbaiki efek imunosupresi dari kemoterapi Adriamycin-Cyclophosphamide. Salah satu komponen Artemisia vulgaris yaitu artemisinin meningkatkan produksi IL-12 oleh makrofag dengan cara menghambat $c$ Jun N-terminal Kinase (JNK) pathway (24). Penelitian lain oleh Langroudi dkk, 2010, juga menyebutkan bahwa Artemisinin berperan meningkatkan imunitas namun dengan cara lain, yaitu dengan menekan jumlah sel Treg (25).

Indeks apoptosis ditemukan lebih tinggi pada kelompok kombinasi kemoterapi dan ekstrak Artemisia vulgaris dibandingkan kemoterapi saja. Hal ini dapat dijelaskan karena artemisinin menghambat fase G1 dari siklus sel, meningkatkan produksi Reactive Oxygen Species (ROS) menyebabkan runtuhnya membrane potensial mitokondria dan memicu pelepasan sitokrom-c dari mitokondria ke dalam sitoplasma, yang akhirnya mengaktifkan apoptosis yang dimediasi oleh Caspase-3 (17). Artemisinin dan derivatnya mempunyai peran proapoptosis tidak hanya dengan pelepasan sitokrom-3 dan over ekspresi $B a x$, namun juga dengan meningkatkan rasio Bax/Bcl-2, mengaktivasi Caspase-3 dan Caspase-9 (27). Selain itu Artemisinin mungkin berinteraksi langsung dengan replikasi DNA dalam proses induksi apoptosis (28). Artemisinin dan derivatnya menyebabkan apoptosis pada 
sel tumor dengan cara meningkatkan kadar kalsium intraseluler dan aktivasi $p 38$ (29). Beberapa penelitian tersebut di atas menunjukkan bahwa ada banyak mekanisme Artemisinin sebagai komponen aktif dari Artemisia vulgaris dalam menginduksi apoptosis.

Penelitian ini juga menemukan korelasi positif kuat yang bermakna di antara kadar IL-12 dengan indeks apoptosis pada kelompok kombinasi kemoterapi AdriamycinCyclophosphamide dan ekstrak Artemisia vulgaris. Temuan ini menjelaskan korelasi kadar IL-12 dan indeks apoptosis, namun masih ada pathway lain yang menyebabkan

\section{DAFTAR PUSTAKA}

1. Mugi W. Deteksi Dini Kanker Leher Rahim dan Kanker Payudara di Indonesia 2007-2014. Di dalam: Kementerian Kesehatan Republik Indonesia (Ed). Buletin Jendela Data dan Informasi Kesehatan. Jakarta: Kementerian Kesehatan Republik Indonesia; 2015: hal. 12-15.

2. Kementerian Kesehatan Republik Indonesia. Panduan Nasional Penanganan Kanker (Kanker Payudara). Jakarta: Komite Nasional Penanggulangan Kanker; 2015; hal. 1-10.

3. Roezin A. Perkembangan Mutakhir Tumor Ganas Payudara. Universa Medicina Fakultas Kedokteran Trisakti. 2005; 24(4): 190-198.

4. Luangdilok S, Samarnthai N, and Korphaisarn K. Association between Pathological Complete Response and Outcome Following Neoadjuvant Chemotherapy in Locally Advanced Breast Cancer Patients. Journal of Breast Cancer. 2014; 17(4): 376385.

5. Das AK. Anticancer Effect of AntiMalarial Artemisinin Compounds. Annals of Medical and Health Science Research. 2015; 5(2): 93-102.

6. Riwanto I, Budijitno S, Dharmana E, et al. Effect of Phaleria macrocarpa Supplementation on Apoptosis and Tumor Growth of $\mathrm{C} 3 \mathrm{H}$ Mice with Breast Cancer Under Treatment with AdriamycinCyclophosphamide. International Surgery. 2011; 96(2): 164-170

7. Majdalawieh AF and Fayyad MW. Recent Advances on the Anti-Cancer Properties of Nigella sativa, a Widely Used Food Additive. Journal of Ayurveda and Integrative Medicine. 2016; 7(3): 173-180.

8. Mbuthia KS, Mireji PO, Ngure RM, et al. Tea (Camellia sinensis) Infusions Ameliorate Cancer in 4TI Metastatic Breast Cancer Model. BMC Complementary and Alternative Medicine. 2017; 17(1): 202-214.

9. Abdulllah M, Syam AF, Meilany S, et al. The Value of Caspase-3 after the Application of Annona muricata Leaf Extract in COLO-205 Colorectal Cancer Cell Line. Gastroenterology Research and Practice. 2017; 2017: 1-5.

10. Choi E and Kim G. Effect of Artemisia Species on Cellular Proliferation and Apoptosis in Human Breast Cancer Cells via Estrogen Receptor Related Pathway. Journal of Traditional Chinese Medicine. 2013; 33(5): 658-663. terjadinya proses apoptosis tersebut (25-29).

Dapat disimpulkan bahwa penambahan Artemisia vulgaris pada kemoterapi meningkatkan kadar IL-12 dan indeks apoptosis sel kanker pada mencit $\mathrm{C} 3 \mathrm{H}$ dengan adenokarsinoma mammae yang diberi regimen kemoterapi Adriamycin-Cyclophosphamide. Korelasi antara kadar IL-12 dengan indeks apoptosis pada mencit $\mathrm{C} 3 \mathrm{H}$ dengan adenokarsinoma mammae yang diberi kombinasi kemoterapi Adriamycin-Cyclophosphamide dan ekstrak Artemisia vulgaris menunjukkan salah satu potensi pathwayapoptosis.

11. Sharmila K and Padma PR. Anticancer Activity of Artemisia vulgaris on Hepatocellular Carcinoma (HepG2) Cells. International Journal of Pharmacy and Pharmaceutical Sciences. 2013; 5(3): 479-483.

12. Saleh AM, Aljada A, Rizvi SA, Nasr A, Alaskar AS, and William JD. In Vitro Cytotoxicity of Artemisia vulgaris L. Essential Oil is Mediated by a MitochondriaDependent Apoptosis in HL-60 Leukemic Cell Line. BMC Complementary and Alternative Medicine. 2014; 14: 226-240.

13. Michaelsen FW, Saeed ME, Schwarzkopf J, and Efferth T. Activity of Artemisia annua and Artemisinin Derivates, in Prostate Carcinoma. Phytomedicine. 2015; 22(14): 1223-1231.

14. Haniya AK, dan Padma PR. Phytochemical Investigation of Methanolic Extract of Artemisia vulgaris L. leaves. International Journal of Pharma and Bio Sciences. 2014; 5(2): 184-195.

15. Aini N, Soebaktiningsih, Fitri LE, Kalsum U, dan Sumarno. Pengaruh Ekstrak Biji Nimba (Azadirachta indica) Terhadap Penurunan Derajat Parasit dan Jumlah Hemozoin pada Kultur Plasmodium falciparum. Jurnal Kedokteran Brawijaya. 2004; 20(3): 115-124

16. Yance DR and Sagar SM. Targeting Angiogenesis with Integrative Cancer Therapies. Integrative Cancer Therapies. 2006; 5(1): 9-29.

17. Jia J, Qin Y, Zhang L, et al. Artemisinin Inhibits Gallbladder Cancer Cell Lines Through Triggering Cell Cycle Arrest and Apoptosis. Molecular Medicine Reports. 2016; 13(5): 4461-4468.

18. Lasek W, Zagozdzon R, and Jakobisiak M. Interleukin 12: Still a Promising Candidate for Tumor Immunotherapy? Cancer Immunology, Immunotherapy. 2014; 63(5): 419-435.

19. Melero I, Mazzolini G, Narvaiza I, Qian C, Chen L, and Prieto J. IL-12 Gene Therapy for Cancer: In Synergy with Other Immunotherapies. Trends in Immunology. 2001; 22(3): 113-115.

20. Alkayyal AA, Mahmoud AB, and Auer RC. Interleukin23-expressing Oncolytic Virus: A Promising Strategy for Cancer Immunotherapy. Journal of Taibah University Medical Sciences. 2016; 11(3): 187-193.

21. Elmore S. Apoptosis: A Review of Programmed Cell Death. Toxicologic Pathology. 2007; 35(4): 495-516.

22. Hassan M, Watari H, AbuAlmaaty A, Ohba $Y$, and Sakuragi N. Apoptosis and Molecular Targeting 
Therapy in Cancer. BioMed Research International. 2014; 2014: 1-23.

23. World Health Organization. Research Guidelines for Evaluating the Safety and Efficacy of Herbal Medicine. (O n I i n e ) 1993 . http://apps.who.int/medicinedocs/en/d/Jh2946e/

24. Cho YC, Lee SH, Lee M, et al. Enhanced IL-12p40 Production in LPS-stimulated Macrophages by Inhibiting JNK Activation by Artemisinin. Archives of Pharmacal Research. 2012; 35(11): 1961-1968.

25. Langroudi L, Hassan ZM, Ebtekar M, Mahdavi M, Pakravan N, and Noori S. A Comparison of Low-Dose Cyclophosphamide Treatment with Artemisinin Treatment in Reducing the Number of Regulatory $T$ Cells in Murine Breast Cancer. International Immunopharmacology. 2010; 10(9): 1055-1061.
26. Jankowitz RC, and Davidson NE. Breast Cancer. In: Boyiadzis MM, Frame JN, Kohler DR, and Fojo T (Eds). Hematology-Oncology Therapy 2nd edition. New York: McGraw-Hill Education; 2014: hal. 102.

27. Li Z, Li Q, Wu J, Wang M, and Yu J. Artemisinin and Its Derivates as a Repurposing Anticancer Agent: What Else Do We Need to Do? Molecules. 2016; 21(10): 1-14.

28. Blazquez AG, Fernandez M, Sanchez L, et al. Novel Artemisinin Derivates with Potential Usefulness against Liver/Colon Cancer and Viral Hepatitis. Bioorganic and Medicinal Chemistry. 2013; 21(14): 4432-4441.

29. Mu D, Zhang W, Chu D, et al. The Role of Calcium, P38 MAPK in Dihydroartemisinin-induced Apoptosis of Lung Cancer PC-14 Cells. Cancer Chemotheraphy and Pharmacology. 2008; 61(4): 639-645. 